\title{
An Empirical Analysis of the Influence of Regional Subsidy on Enterprise Value
}

\author{
Yue Qiao \\ Shanghai University of Finance and Economics, Shanghai, China \\ Email: qiaoyweiwu@163.com
}

Received 24 May 2015; accepted 20 July 2015; published 23 July 2015

Copyright (C) 2015 by author and Scientific Research Publishing Inc.

This work is licensed under the Creative Commons Attribution International License (CC BY). http://creativecommons.org/licenses/by/4.0/

cC) (7) Open Access

\begin{abstract}
Based on the local listed companies in pharmaceutical industry as samples, this article inspects the influence of regional subsidies on the industries and the companies in it. The results show that the regional subsidies have no positive effects on the cross-regional enterprises whereas the support promotes the value of local enterprises. Guided by the composition of the market value, this article researches the reasons from the perspective of profit and development capacity. This article finds that the regional subsidies have no intensive strength to the $R \& D$ (Research and Development) capacity in the cross-regional enterprises and the relationship between the regional subsidies and the operating profits behaves completely different among cross-regional enterprises and local enterprises. Based on the empirical analysis, this article concludes that the effects of regional subsidies behave completely different among the cross-regional enterprises and the local enterprises, which can be explained by the short-time and long-time analysis.
\end{abstract}

\section{Keywords}

Regional Subsidy, Enterprise Performance, R \& D

\section{Introduction}

As the cells of the economies, the company lays its growth on the promotion of its value. The value of the enterprise is the enterprise expected present value of cash flow, using the weighted average cost of capital for the discount rate. It is closely related to the enterprise's financial decisions and reflects the risk and sustainable development ability of an enterprise.

Because of this, the regional helps enterprises through various forms of regional subsidies each year. If the support makes an effect, the regional should guide the enterprise to use the subsidies properly to raise the value of company. Through the research on the statistics of the 89 listed enterprises from 2007 to 2012, this article 
analyzes the enterprises for the utilization of the regional subsidies.

This article aims at answering the problems as follows: How does the regional subsidy affect the local and cross-region companies? Why does the effect of the regional subsidy arise from? First, this article researches the effect of the regional subsidy on the market value of companies. Second, Guided by the composition of the market value, this article researches the reasons from the perspective of profit and development capacity by analyzing the correlation index. Finally, this article introduces the free cash flow to do further research.

\section{Influence of Regional Subsidy}

Hong Zhou and Jiuqin Lu stated its opinions on the effect of the regional subsidies on the value of enterprises [1]. They said that regional subsidies have negative effects on the value of enterprises if it occurred one year ago. However, the supports have the positive effects if enterprises achieve the subsidies one year ago and this year. Dong Lu, Gao Lin and Dan Yang analyzed the statistics of the companies on the gem of China, they found that the companies on the gem generally seized the regional subsides by their relationship with the region [2]. The positive relationship between the ability of research and development only exists in the enterprises having no relationship with the region and the positive relationship between the value of the enterprises and the ability of research and development only exists in the enterprises gaining no regional subsidy. Yan Jiang and Kunru Tian researched on the internal characteristics and stability of the listed corporate governance [3]. They concluded that regional subsidies make the debt constraints more released and raise the debt risk. Zhihao Yu, Yuanhao Ye and Nan Lu considered that the effect of regional subsidies on the value of enterprises is complex through their analysis [4]. On the one hand, the regional subsidies can promote the local resource allocation and the performance of enterprises. On the other hand, the enterprises may use the support as an instrument to make a dramatic change in their financial reports. This means that it may make no promotion on enterprises' competitive strength.

Yali Liu, Mandi Zhang, Xiaoyan studied the relationship between fiscal decentralization, corporate rentseeking and local subsidy [5]. They concluded that corporate rent-seeking helps them get government subsidies and government subsidies exists ownership discrimination. The soft budget constraint problems of state-owned enterprises are still outstanding. Xiao Chen, Jing Li considered that the regional subsidies in real estate industry have nothing to do with state-owned nature of the enterprise, and is associated with the asset scale and sales scale of enterprise [6]. The asset scale and sales of the larger companies are more likely to receive government subsidies [6]. Enping Jiang, Yunsen Chen and Song Zhu considered regional subsidies can only solve the problems of the company a short time from the perspective of the listed company itself, but not fundamentally improve enterprise core competitive ability [7] [8]. Weizhang Sun Shengdao Gan, Qinye Zhou and Changqing Zhou Concluded that Government subsidies are not significantly associated with the current performance of listed companies in the IT industry [9] [10].

According to the review of former articles, the scholars laid their emphasis on the reasons of the regional subsidy and the short-time effect of it. They failed to study the effect on the market value of a company. This article studies not only the effect, but researches the reasons from short-time performance to long-time R \& D capacity.

\section{Research Designs}

\subsection{Hypothesis}

Through the summary of the former articles, the scholars generally hold that the regional subsidies generally have no effects on the enterprises' value. According to these researches, this article aims at researching the extent of the effects of regional subsidies. Based on the topic, this article makes hypothesizes as follows:

First, regional subsidies have positive effect on the Local enterprises and have negative effect on the Crossregional enterprises.

Second, the regional subsidies add the free cash flow in the Cross-regional enterprises and have almost no relationships with the change of those in Local enterprises.

\subsection{Sample Selection}

The samples of this article come from 89 public enterprises of pharmaceuticals industry listed on the Shanghai Stock Market and Shanghai Stock Market in China, which distributes in the 31 provinces in China. There are 43 
the cross-region company. This article chooses their statistics on these enterprises' financial reports and related reports from 2007 to 2012, especially the information about the research and development of intangible assets. The basic information of enterprises and tax preferences policies come from the related database and the news. Concretely, they come from the Huge Influx of Information Network.

\section{Results of the Empirical Analysis}

\subsection{Overall Analysis}

First, this article calculated the market value of enterprises. By using Stata 12.0, the relationship between the regional subsidy and the market value is estimated in Table 1.

Table 1 shows that the relationship between the regional subsidies and the value of enterprises. As the statistics in the table shows, the regional subsidies have no positive effect on the Cross-regional enterprises whereas the support promotes the value of Local enterprises. As to the Local enterprises, the regional subsidies help them raise their values. And the correlation rate generally added with the as time went on.

\subsection{Specific Analysis}

According to the statistics from the financial reports of the listed enterprises, the relationship between the regional subsidy and R \& D is estimated in Table 2 by using Stata 12.0 .

According to the calculation in the table, this article concluded that the regional subsidies have no intensive strength to the research and development in the Cross-regional enterprises because the correlation rate between them behaved negative in these few years. However, the relationship of them behaved positive in the Local enterprises and the correlation rate was stable at about 0.2. This means that the regional subsidies have the positive effect on the research and development ability among the Local enterprises.

Generally, the relationship between the regional subsidy and R \& D in the enterprises behaves as the Equation (1) and Equation (2).

$$
\begin{aligned}
& V=v\left(\frac{\mathrm{R} \& \mathrm{D}}{\mathrm{SUB}}\right) \\
& \mathrm{MPK}=\frac{R(r+\sigma)(1+s)}{p}
\end{aligned}
$$

Equation (1) means that if an enterprise uses more regional subsidies in the $\mathrm{R} \& \mathrm{D}$ activities, its value may be added in the coming years. The signal $V$ represents the value of an enterprise and the signal SUB means the

\begin{tabular}{|c|c|c|c|c|c|c|}
\hline The type of enterprises & 2007 & 2008 & 2009 & 2010 & 2011 & 2012 \\
\hline Cross-regional enterprises & -0.1233 & -0.0452 & 0.0031 & -0.1272 & -0.1544 & -0.0826 \\
\hline Local enterprises & 0.2483 & 0.1251 & 0.1979 & 0.1928 & 0.2159 & 0.1060 \\
\hline National enterprises & 0.0625 & 0.0400 & 0.1005 & 0.0328 & 0.03075 & 0.0317 \\
\hline private enterprises & 0.1554 & 0.0826 & 0.1492 & 0.1128 & 0.1233 & 0.0689 \\
\hline
\end{tabular}

Table 1. Relationship between the value of enterprises and regional subsidies.

Table 2. Relationship between the R \& D in enterprises and regional subsidies.

\begin{tabular}{ccccccccc}
\hline The type of enterprises & Year & 2007 & 2008 & 2009 & 2010 & 2011 & -0.1431 & -0.0975 \\
Cross-regional enterprises & -0.0246 & -0.1306 & 0.1019 & -0.0778 & 0.2517 & 0.2025 \\
Local enterprises & 0.4355 & 0.3799 & 0.2493 & 0.0543 \\
National enterprises & 0.2055 & 0.1247 & 0.1756 & 0.0627 & 0.13295 & 0.153 \\
private enterprises & 0.3205 & 0.2523 & 0.21245 & & 0.1374 \\
\hline
\end{tabular}


amount of regional subsidy. In the Equation (2), the signal MPK means that the marginal product of the capitals in the enterprise and the signal $\sigma$ represents depreciation rate. The signal $r$ and $s$ represents the discount rate and the regional subsidies rate. Finally, the signal $P$ represents the price index. Through this model, we can conclude that the higher regional subsidies bring the more initiative in the research and development activities in normal case.

Guided by the operating profit from the financial reports of the listed enterprises, the relationship between the regional subsidy and operating profit is estimated in Table 3 by using regression analysis.

On the basis of the statistics on the table, the relationship between the regional subsidies and the operating profits behaved completely differently among Cross-regional enterprises and Local enterprises. As for the Cross-regional enterprises, the two indexes are negatively related in the five years, which means that the support of the regional restrains the promotion of the enterprises development. However, the support not only raises the profits of the local enterprise in the five years but also the correlation rate gradually rises as time went on. This phenomenon shows that the regional subsidies played a more positive role in the development in the Local enterprises.

Depending on the tax expenses from the financial reports of the listed enterprises, the relationship between the regional subsidy and tax expenses is estimated in Table 4 by using regression analysis.

As to the Cross-regional enterprises, the relationship between the regional subsidies and the tax expenses presented negative in four years. This means that the region support to the Cross-regional enterprises failed to achieve the expected harvest because the Cross-regional enterprises failed to do more for the development of the region. As a result, this article considers that the regional subsidies to the Cross-regional enterprises are completely a waste. However, the two indexes are strongly related among the Local enterprises, which mean the efforts in the society have gained expected returns. The analysis of this part has also demonstrated the value of Local enterprises is highly positive related with the regional subsidies.

Along with the former analysis, the ability of $\mathrm{R} \& \mathrm{D}$ represents the potential of an enterprise and the current performance represents the current strength of an enterprise. Both decided the value of an enterprise together. And through the analysis, the conclusion in the overall analysis can be explained perfectly. The results are presented in Table 5.

By searching the data of the free cash flow from the financial reports of the listed enterprises, the regression analysis result about the relationship between the regional subsidy and the free cash flow is estimated in Table 5.

Being the same as the former, this article divided the enterprises into the Cross-regional enterprises and the Local enterprises. Through the calculation of the correlation rate, this article found that the free cash flow was almost unrelated with the regional subsidies, which means that the regional failed to change the free cash flow among the Local enterprises. As for the Cross-regional enterprises, the two indexes behaved strongly positive

Table 3. Relationship between operating profit of enterprises and regional subsidies.

\begin{tabular}{ccccccc}
\hline Year & 2007 & 2008 & 2009 & 2010 & 2011 \\
The type of enterprises & -0.1436 & -0.0758 & -0.1863 & -0.1258 & -0.1731 & -0.1183 \\
Cross-regional enterprises & 0.4001 & 0.0558 & 0.2040 & 0.1687 & 0.3115 \\
Local enterprises & 0.1283 & -0.0100 & 0.0089 & 0.0215 & 0.0692 \\
National enterprises & 0.2642 & 0.0229 & 0.1065 & 0.0951 & 0.1904 \\
private enterprises & & & 0.1968 \\
\hline
\end{tabular}

Table 4. Relationship between the tax expenses of enterprises and regional subsidies.

\begin{tabular}{cccccccc}
\hline The type of enterprises & Year & 2007 & 2008 & 2009 & 2010 & 2011 & -0.1907 \\
Cross-regional enterprises & 0.0402 & -0.0612 & 0.2305 & -0.1048 & 0.3568 \\
Local enterprises & 0.5550 & 0.5245 & 0.3109 & 0.4999 & 0.3535 \\
National enterprises & 0.2976 & 0.2317 & 0.2707 & 0.1996 & 0.1387 \\
private enterprises & 0.4263 & 0.3781 & 0.2908 & 0.3498 & 0.2199 \\
\hline
\end{tabular}


relationship in the five years, which means that the regional subsidies turned the ability of the operation among the Cross-regional enterprises down.

In order to the comprehensive research, the three-dimensional analysis will be used for further discussion. Next, this article will estimate the relation between the immediate profits, R \& D capacity and the value of the company by data fitting. The results are presented in Figure 1.

According to actual statistics, the change of the market value is irregular because the subsidy lays too much emphasis on a certain field and generally the other. That is to say, if an enterprise focuses only on the immediate profit or the R \& D capacity, its market value will fail to behave better. The highest market value is the point when the immediate profit is 0.4 and the R \& D capacity is 0.45 according to Table 2 and Table 3.

This article estimates the best improving path according to the actual statistics by using Matlab 7.0. The estimated equation is presented as follows:

$$
V=\frac{\left(5 *(\mathrm{R} \& \mathrm{D})^{3}+P^{2}+\exp \left(-(\mathrm{R} \& \mathrm{D})^{2}-P^{2}\right)\right)}{8}
$$

According to Figure 1, the balanced development of the immediate profit and the R \& D capacity will brings the rapid advancement of the market value, especially after the $(0.2,0.5)$ point.

In addition, the market value behaves more flexible in the field of R \& D capacity.

\section{Discussions}

This article discusses the effect of regional subsidy on the market value and its compositions. The present studies concluded that a wide range of existence of the local protectionism. This article demonstrates this opinion from a unique perspective. A region cannot take control of the cross-region company completely. The cross-

Table 5. Relationship between the free cash flow and regional subsidies.

\begin{tabular}{|c|c|c|c|c|c|c|}
\hline The type of enterprises & 2007 & 2008 & 2009 & 2010 & 2011 & 2012 \\
\hline Cross-regional enterprises & -0.2219 & -0.0027 & 0.0996 & 0.3727 & 0.2697 & 0.4038 \\
\hline Local enterprises & 0.0554 & 0.0494 & 0.0689 & -0.0596 & -0.2503 & 0.0176 \\
\hline National enterprises & -0.0833 & 0.0234 & 0.0843 & 0.1566 & 0.0097 & 0.1226 \\
\hline private enterprises & -0.0140 & 0.0364 & 0.0766 & 0.0485 & -0.1203 & 0.0701 \\
\hline
\end{tabular}

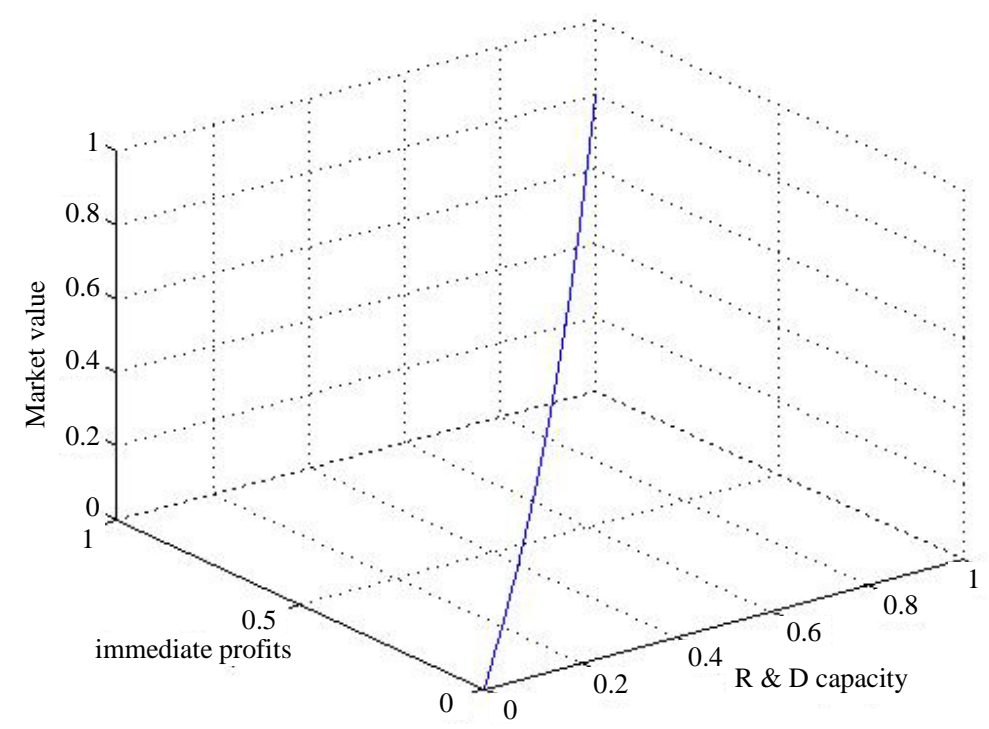

Figure 1. A proper path of the value of an enterprise. 
region companies' value relies on its business in several regions. A region aims at protecting its local companies. The more regional subsidies mean the more intervention. So the regional subsidy is to protect the local company. The empirical results can be explained.

Guided by the market value model, this article finds the reasons. Because the market value is calculated by the present value of future cash flow. And the future cash flow consists of the present performance and the capacity of R \& D. The present studies showed that the subsidy can add the performance of companies and also can reduce it. The local companies in the pharmaceutical industry make perfectly use of the subsidy to raise their present performance and the capacity of $\mathrm{R} \& \mathrm{D}$. So this article supports that the subsidy has positive effect on the companies. However, the local subsidy is to protect its own companies. So the present performance and the capacity of R \& D are negative correlated with the local subsidy, which lead to the relationship between the local subsidies with the cross-region companies.

\section{Final Remarks}

Through the comprehensive research, this article has the conclusions as follow. According to the calculation, this article concludes that the regional subsidies bring the negative effect among the Cross-regional enterprises whereas bring the positive effect among the Local enterprises. Then it comes the reasons:

First, as to the long-term indexes, the effect of regional subsidies behaves completely different among the Cross-regional enterprises and the Local enterprises.

Second, as to the short-term indexes, the effect of regional subsidies behaves completely different among the Cross-regional enterprises and the Local enterprises.

Third, as to the tax expenses indexes, the effect of regional subsidies behaves completely different among the Cross-regional enterprises and the Local enterprises.

Fourth, as to the free cash flow indexes, the effect of regional subsidies behaves completely different among the Cross-regional enterprises and the Local enterprises.

\section{References}

[1] Zhou, H. and Lu, J.Q. (2012) The Regional Subsidies Affect Research and Development to Create Enterprise Value. Proceedings of the Special Symposium Committee Professional Basic Theory of Accounting in 2012 Chinese Accounting Association, Southwestern University of Finance and Economics, Chengdu, 4-82.

[2] Lu, D., Lin, G. and Yang, D. (2012) The Regional Subsidies, Spending on Research and Development and Market Value-Empirical Evidence from the Gem of High-Tech Enterprises. 9th Edition, Investment Research, 67-81.

[3] Jiang, Y. and Tian, K.R. (2013) Cross-Regional Listing Corporation Internal Features Regional Grants and Accounting Conservatism. Commerce College in Tianjin University of Finance and Economics, Research on Auditing and Economic. 1st Edition, 77-86

[4] Xu, G., Zhu, W.D. and Zhang, Z.Y. (2012) Corporate Rent-Seeking and Local Government Subsidies-Empirical Evidence from China's Capital Market. 3rd Edition, Journal of Finance and Economics, 65-77.

[5] Liu, Y.L., Zhang, M.D. and Ma, X.Y. (2010) The Influence of Local Government Subsidies to the Real Estate Listed Company Performance. The Accounting Issue, 12, 51-54.

[6] Chen, X. and Li, J. (2001) The Research on the Role of Financial Behavior of Local Subsidy in Promoting Listed Companies Performance. Accounting Research, 12, 20-29.

[7] Jiang, E.P. (2013) the Research on Local Government Subsidies and the Listed Company Earnings Management. 14th Edition, Business Accounting, 106-108.

[8] Chen, Y.S. and Zhu, S. (2009) Political Relations, System Environment and the Capital Investment of Listed Companies. 12th Edition, Journal of Study on Finance and Economics, 27-39.

[9] Sun, W.Z. and Dao, G.S. (2012) Research on the impact of ownership structure on Corporate Performance. 20th Edition, Economic Problems, 20-28.

[10] Zhou, Q.Y. and Zhou, C.Q. (2005) The Impact of Non-Recurring Profit and Loss on the Financial Results of Listed Companies in the Shanghai Market Research. 1st Edition, Journal of Shanghai Lixin University of Commerce, 1-8. 